\title{
Analysis of Rh Blood Type Antibody Specificities of Transfused Patients in the Sichuan Area of China
}

\section{Cuiying $\mathrm{Li}^{\star}$, Li Zhang, Fei Huang, Jie Xiao, Hong Xu and Zhewen He}

Department of Blood transfusion of Chengdu Military Region General Hospital, Sichuan, Chengdu-610083, China

"Corresponding author: Cuiying Li, Department of Blood transfusion of Chengdu Military Region General Hospital, Rongdu Road 270, Jinniu District, Chengdu, Sichuan-610083, China, Tel: 8628-86570389, 13808003840; Fax: +8628-86570389; E-mail: 1483883255@qq.com

Received date: Aug 07, 2015, Accepted date: Aug 31, 2015, Publication date: Sep 04, 2015

Copyright: (C) $2015 \mathrm{Li} \mathrm{C}$, et al. This is an open-access article distributed under the terms of the Creative Commons Attribution License, which permits unrestricted use, distribution, and reproduction in any medium, provided the original author and source are credited.

\begin{abstract}
Objective: Rh blood type antibody specificities of transfused patients in the Sichuan area of China were analyzed to reduce immune haemolytic transfusion reactions and improve the safety of clinical blood transfusion.

Methods: The micro-column gel method was introduced to screen irregular antibodies in patient blood samples between June 2015 and June 2006 in our hospital. The antibody specificities of antibody-positive samples were identified, and the type and proportion of antibodies were analyzed.
\end{abstract}

Results: A total of 130,866 samples of transfused patients were tested. The number of irregular antibody-positive cases was 1127 (positive rate $=0.86 \%[1127 / 130,866]$ ). The number of specific antibody cases was 576 (positive rate $=51.11 \%$ [576/1127]). Among the positive cases, Rh type antibodies were shared in $78.29 \%$ of patients $(451 / 576)$ and the number of anti-E cases was 358; Rh type antibodies existed in $79.37 \%$ of patients (358/451). The number of patients without a history of blood transfusion and pregnancy was 103; Rh type antibodies were shared $28.77 \%(103 / 358)$ in all anti-E cases.

Conclusion: It is very important to screen for red cell irregular antibodies, especially Rh type antibody, before transfusion. The detection of $\mathrm{Rh}(\mathrm{E})$ antigen in transfused patients and transfusion with the same type blood are also important.

Keywords: Rh blood type antibodies; Specificity

\section{Introduction}

Screening for irregular antibodies in red blood cells has been widely used in the diagnosis and prevention of transfusion reactions, which is especially important for pregnant patients and patients with a blood transfusion history or a large number of blood transfusions over a short period of time. The detection rate of irregular antibodies in Chinese Han patients is $0.382 .38 \%$, which is the main reason for adverse reactions of blood transfusions, hemolytic disease of the newborn (HDN), difficulties in blood type identification and matching, anemia for unknown reasons, and invalid red blood cell transfusion [1,2]. Irregular antibody screening before blood transfusion to identify irregular antibodies with clinical significance, especially screening and identification of $\mathrm{Rh}$ blood type system antibodies, is important for clinical safety and efficacy of blood transfusions.

\section{Materials and Methods}

\section{Sample source and processing}

A total of 130,866 transfused patients between June 2015 and June 2006 in the Chengdu Military Region General Hospital were collected. Among the patients, 73,284 were males and 57,582 were females. All patients were Han nationality, and ranged in age from 1-91 years of age. Venous blood $(3 \mathrm{ml})$ was extracted from the patients. After anticoagulation with EDTA, the supernatant was separated by centrifugation and stored at 4 .

\section{Irregular antibody screening}

The micro-column glass bead method was performed. A microcolumn gel card (Ortho Clinical Diagnostics Company, (New Jersey, USA) was tested using an automatic blood type instrument (ORTHO Auto Vue Innova, (New Jersey, USA). Dilution, sample addition, incubation, centrifugation, and the results were automatically completed by the instrument; the operation was performed in accordance with the instructions of the implementation.

\section{Irregular antibody identification}

The micro-column gel method was used. Samples from antibodypositive patients were agglutinated with spectral red blood cells (Shanghai Blood Bio Pharmaceutical Products Co., Ltd., Shanghai, China) brine, and anti-human sphere medium (micro-column gel card). The specificity of antibody was determined according to the response pattern of red blood cells.

\section{Self-antibody identification}

The serum and red blood cells were reacted in salt water and antihuman medium, and the results were judged as positive or negative [3]. 
Citation: Li C, Zhang L, Huang F, Xiao J, Xu H, et al. (2015) Analysis of Rh Blood Type Antibody Specificities of Transfused Patients in the

Page 2 of 3

\section{Results}

\section{Results of irregular antibody screening and specific antibody identification}

A total of 130,866 samples from transfused patients were tested. The irregular antibody-positive cases numbered 1127; the positive rate was $0.86 \%(1127 / 130866)$. The number of specific antibody cases was 576 ; the positive rate was $51.11 \%(576 / 1127)$. Rh type antibody was shared by $78.29 \%$ of cases $(451 / 576)$ and anti-E538 was expressed in $79.37 \%$ of Rh type antibodies (358/451). The identification of irregular antibodies in the Rh system is shown in Table 1.

\begin{tabular}{|c|c|c|c|}
\hline $\begin{array}{l}\text { Blood group } \\
\text { system }\end{array}$ & Antibody type & Number & $\begin{array}{l}\text { Detection } \\
\text { frequency (\%) }\end{array}$ \\
\hline \multirow[t]{13}{*}{ Rh-hr } & anti-E & 358 & 79.38 \\
\hline & anti-c & 21 & 4.66 \\
\hline & anti-D & 20 & 4.43 \\
\hline & anti-Ec & 15 & 3.33 \\
\hline & anti-e & 15 & 3.33 \\
\hline & anti-Ce & 5 & 1.11 \\
\hline & anti-C & 4 & 0.89 \\
\hline & anti-E/anti-Mur & 3 & 0.67 \\
\hline & Self-anti-C/anti-e & 3 & 0.67 \\
\hline & anti-E/anti-Fyb & 3 & 0.67 \\
\hline & anti-C/anti-D & 2 & 0.44 \\
\hline & Self-anti-C & 1 & 0.22 \\
\hline & anti-E/anti-S & 1 & 0.22 \\
\hline
\end{tabular}

Anti-C/anti-D, self-anti-C/anti-e, anti-E/anti-Fyb, anti-E/anti-Mur, and anti-E/anti$\mathrm{S}$ : indicated expression at the same time.

Table 1: Identification results of irregular antibodies in Rh system.

A history of blood transfusion with anti-E positive specimens and pregnancy is shown in Table 2. There were 358 anti-E cases (131 males and 277 females). The number of patients without a history of blood transfusion and pregnancy was 103; Rh type antibody was shared in $28.77 \%(103 / 358)$ of anti-E cases.

\begin{tabular}{|l|l|l|l|l|l|}
\hline & $\begin{array}{l}\text { Without } \\
\text { blood } \\
\text { transfusion }\end{array}$ & $\begin{array}{l}\text { Blood } \\
\text { transfusion }\end{array}$ & $\begin{array}{l}\text { Pregnancy } \\
\text { history }\end{array}$ & $\begin{array}{l}\text { Without } \\
\text { pregnancy } \\
\text { history }\end{array}$ & $\begin{array}{l}\text { No } \\
\text { record }\end{array}$ \\
\hline Male & 56 & 47 & $/$ & $/$ & 28 \\
\hline Female & 36 & 39 & 120 & 8 & 24 \\
\hline l: & & & & \\
\hline
\end{tabular}

I: indicates non-statistical data.

Table 2: History of blood transfusion and pregnancy in anti-E positive specimens.

\section{Discussion}

Patients with the same type of antibody in serum who have received a red blood cell transfusion with the corresponding antigen are likely to have a hemolytic transfusion reaction. To avoid the occurrence of transfusion reactions and reduce invalid red blood cell transfusions, it is necessary to screen and identify irregular antibodies before the transfusion is performed.

Based on our results, amongst 130,866 patients with blood transfusions between June 2015 and June 2006, the irregular antibody screening positive rate was $0.86 \%$ and the positive rate for specific antibodies was $51.11 \%$. Irregular antibody screening and specificity determination should be performed on patients who need blood transfusions before no corresponding antigen red blood cells or crossmatched red blood cells were transfused to achieve safe and effective blood transfusions.

Our results showed that iso-antibodies belonged to the Rh blood type system in $78.29 \%$ of cases. Anti-E antibody was the most common type, accounting for $79.37 \%$ of cases. The number of anti-E patients without a blood transfusion or pregnancy history was 103, accounting for $28.77 \%$ of all anti-E cases. In clinical blood transfusion, the importance of Rh blood type system is second only to the ABO blood type system.

At present, all hospitals in China perform Rh (D) antigen detection; however, other blood type antigens of the Rh system have not been included in routine detection, which inevitably leads to the possibility of an immune response. It has been reported that $\mathrm{Rh}(\mathrm{E})$-negative cases account for approximately $40 \%$ of all routine $\mathrm{Rh}(\mathrm{E})$ antigen detections for blood receptors [4]. Therefore, in addition to the screening of irregular antibodies to red blood cells before blood transfusion, the detection of $\mathrm{Rh}(\mathrm{E})$ antigen in blood transfusion patients and transfusions with the same type of blood are also important [5-10].

\section{Reference}

1. Wu Y, Liu Y, Liu X (2007) Investigation on the distribution of irregular antibodies in Han patients (30800 case) and pregnant women (4200 cases). The Journal of the Fourth Military Medical University 28: 922-925.

2. Feng Gao (2007) Clinical transfusion and inspection. (2nd edn.) Beijing: People's Health Publishing House: 71.

3. Liu D (2002) Immune hematology. Shanghai: Shanghai Science and Technology Press: 65-68.

4. Tang C, Liu B, Fang L (2000) IgM, IgG anti-E lead to 1 cases of incompatible blood. Chinese Journal of Blood Transfusion 13: 191.

5. Andersen AS, Praetorius L, Jørgensen HL, Lylloff K, Larsen KT (2002) Prognostic value of screening for irregular antibodies late in pregnancy in rhesus positive women. Acta Obstet Gynecol Scand 81: 407-411.

6. Moise KJ (2005) Red blood cell alloimmunization in pregnancy. Semin Hematol 42: 169-178.

7. Chen J, Chen Q, Song N (2008) Current status of irregular antibody screening and rare blood group. Chinese Journal of Blood Transfusion 21: 792-794.

8. Li C, Xu H, He H (2010) Anti -C, anti, anti -e were detected in 1 Cases. Chinese Journal of Blood Transfusion 23: 478-479. 
Citation: Li C, Zhang L, Huang F, Xiao J, Xu H, et al. (2015) Analysis of Rh Blood Type Antibody Specificities of Transfused Patients in the Sichuan Area of China. J Blood Disord Transfus 6: 303. doi:10.4172/2155-9864.1000303

Page 3 of 3

9. Li C, Huang F, Xu H (2013) 1 cases of $\mathrm{RhD}$ positive variant type and serum were detected with anti $-\mathrm{D}$ analysis. Chinese Journal of Blood Transfusion 26: 871-872.
10. Xu H, Li C, Huang F (2013) IgM, IgG anti -E induced blood type 1 cases of positive and negative stereotypes. Chinese Blood Transfusion Journal 26: 185-186. 